\title{
Carriers, Entrepreneurs, and Epistemic Power-a Conceptual Toolbox toward an Understanding of Genocide Knowledge
}

Part I of this book examined how social interactions and inner reflections, some expressed in writing, generate knowledge about ongoing and past mass violence. Silencing, acknowledging, and denying are common strategies, distributed unevenly across groups and over time. Part II explores repertoires of knowledge as properties of social collectivities. Following this theoretical excursus, I specifically seek to display what the Turkish and Armenian peoples know about the events of 1915 and subsequent years. Throughout, I use the word people with caution, mindful of variation within each of the two ethno-national groups.

Introducing the term carrier group, this chapter recognizes that some knowledge, including knowledge about the past, is the property of groups, transmitted across generations. Different groups may develop, through millions of interactions and reflections, distinct and at times clashing knowledge repertoires-that is, clusters of taken-for-granted notions of specific phenomena (as described in chapters 1 and 2). Knowledge thus negotiated becomes sedimented (Berger and Luckmann 1966:67-72) and relatively resistant to change. Nonetheless, and in line with Maurice Halbwachs's (1992) thesis on the presentism of collective memory, knowledge is subject to later modifications, especially when it is marred by ambiguities, gaps, and contradictions, as knowledge about mass violence typically is. Modifications of established knowledge are also likely when strategic actors in advantaged institutional positions seize opportunities to promote knowledge change. Those actors are knowledge entrepreneurs or, where knowledge about the past is at stake, memory entrepreneurs (Schwartz 1991, 2003; Fine 2001). These entrepreneurs may hold substantial epistemic power. In the following sections, I detail these concepts and 
arguments. I apply them to the cases of Turkish and Armenian knowledge about the Armenian genocide in chapters 4 and 5 .

\section{CARRIER GROUPS AND KNOWLEDGE}

Maurice Halbwachs_noted French sociologist, a student of Émile Durkheim, and later a victim of Nazi Germany's concentration camps-examined how knowledge develops in social groups. He famously coined the term collective memory, by which he meant knowledge about the past that is shared, mutually acknowledged, and reinforced by a collectivity (Coser 1992). Halbwachs (1992) thereby recognized that memory is the property of social groups. To be sure, individuals remember, but Halbwachs showed how group processes shape what they think about the past. ${ }^{1}$ Group boundaries are also boundaries of shared memories.

A different line of sociological thought aligns well with Halbwachs's notion of collective memory, and it provides an additional building block to our understanding of group-specific knowledge, including knowledge about mass violence and genocide. Max Weber (1978) wrote about carrier groups to refer to collectivities such as social classes, ethnic groups, and formal organizations that are associated with specific ideas or religious beliefs and carry them across time, even across generations (see Kalberg 1994, 2014; Gorski 2003). Members take these ideas and beliefs for granted, and they reaffirm them. Knowledge and ideas become doxathat is, taken-for-granted, unquestioned assumptions about the world.

Building on Weber, Karl Mannheim (1986, [1936] 1985) applied the notion of carrier groups to the sociology of knowledge. Like Weber, he highlighted social classes as carriers. ${ }^{2}$ He further acknowledged-in fact, he stressed-the overlap of different types of groups or units of social organization. His term generation units, for example, refers to groups of persons who are not just part of the same birth cohort, having thus experienced the same historical events in their formative years, but who additionally have been exposed to similar structures of experience (Mannheim 1952). ${ }^{3}$ Such structures are likely to vary along lines of social class, religion, ethnic group membership, or skin color. In other words, Mannheim was mindful of the intersectionality of knowledge.

The association between groups and knowledge often results from interestbased affinities. For a prominent historical example, consider bourgeois classes of the eighteenth and nineteenth centuries. Drawing their strength from ownership of capital and their position in expanding markets for goods and services, they experienced the impediment of traditional status-group distinctions embedded in aristocratic society. They were receptive to enlightenment ideas, to principles of formal liberty and the equality of individuals. Intellectuals, philosophers, writers, and poets may have been the producers of these notions. Yet their ideas would have dissipated had they not attached themselves to receptive social classes that provided them with stability and endurance. 
As in the case of generations, class membership interacted with other traits, including nationality. In France, for example, enlightenment ideas originated with members of the nobility such as Charles-Louis de Secondat, Baron de La Brède et de Montesquieu. In his 1748 book on The Spirit of Laws, Montesquieu had famously proposed the division of government powers, and this notion became one of the foundations of modern democratic constitutions. Class coalitions took different shape in Germany, where Karl Mannheim (1986) closely examined the emergence of a specific type of nineteenth-century conservatism. He identified the royal bureaucracy, nobility, and underdeveloped middle classes as carriers of conservative thought. These groups privileged thinking that was concrete (favoring folk tradition as opposed to abstract ideas of individual rights) and holistic (focusing on the nation as a whole), and they advanced nation-based romanticism (see also Elias [1939] 2000; Kalberg 1987; Gorski 2003). Such a worldview reflected mistrust in the enlightenment, partly in response to the French Revolution with its call for equality, liberty, and solidarity and its abstract notion of rights. Again, the link between group membership and ideological identification may be country specific. It is never straightforward.

Knowledge may also directly grow out of the lived experience of social groups, including the experience of violence. Collectivities exposed to violence are often defined by national, ethnic, or religious characteristics. Their background and experience combine to shape them into carrier groups with distinct memories of atrocity. Knowledge repertoires of perpetrator and victim groups frequently offer the starkest contrast, and they may clash in mnemonic struggles. Chapters 4 and 5 explore Armenians and Turks as carriers of starkly conflicting knowledge repertoires about the Armenian genocide. Chapters 7 and 8 examine struggles.

\section{FLEXIBILITY OR INERTIA OF KNOWLEDGE?}

The notion of carrier groups might suggest stability of knowledge over time. Yet the following chapters show flexibility as well. What social forces might then induce shifts in knowledge within carrier groups? What are the limits of such mutability? Thankfully, several lines of sociological scholarship provide us with tools that guide us through the analyses of the following chapters. They inspire a thesis, an antithesis, and a synthesis.

\section{Thesis: Flexibility and Presentism}

On one side of the divide, we find Maurice Halbwachs's argument about the presentism of collective memory. By presentism, Halbwachs meant that current-day interests and needs of social groups tend to affect their knowledge about the past. Images of historical events, in this line of thought, are always subject to change. Applied to our topic, knowledge about past mass violence likely takes new shape over time and from generation to generation. Halbwachs exemplified his 
argument by tracing shifting ideas about the topography of the Holy Land over several centuries, as Lewis Coser summarizes in his introduction to Halbwachs's work: "The Jerusalem, say, of the Persians, the Romans, the Jews and the Christian crusaders described a landscape that shifted rapidly in character depending on the various nation-states that dominated the Holy Land over a long span of time" (Coser 1992:28).

More recent empirical evidence supports presentism arguments about the flexibility of knowledge. Weil (1987), for example, shows that an astonishingly high percentage of Germans held on to the notion of Hitler as a great political leader in the immediate years after the end of World War II. Yet these attitudes changed substantially during the 1960s, largely driven by new birth cohorts who were not socialized under the Nazi regime (cohort effect). Older cohorts, indoctrinated under Nazi rule, eventually followed suit (period effect). For the United States, Schwartz and Schuman (2005) identify changes in the popular memory of Abraham Lincoln, especially after the civil rights movement. Of various traditional images of Lincoln, including those of the savior of the Union and the man of the people, the notion of the abolitionist, the great emancipator, eventually prevailed. Even where memories are carved in stone, including memories of violence, later modifications and uses by visitors may change the meaning of the memorial site-for example, from the somber to something patriotic, even heroic. Wagner-Pacifici and Schwartz (1991) offer an impressive example of this in the Vietnam Veterans Memorial.

In short, presentism of memory is a force with which to contend. Knowledge, even if held by carrier groups, is subject to modifications. It is always living knowledge.

\section{Antithesis: Signification, Sedimentation, and Inertia of Knowledge}

Despite such support for the notion of flexible knowledge repertoires and the presentism of collective memory, scholarship has also produced arguments that suggest at least relative inertia of knowledge. Peter Berger and Thomas Luckmann (1966), for example, in The Social Construction of Reality, write about the objectivation, signification, and sedimentation of knowledge (see also Zerubavel 2016). Objectivation is the process through which subjective meanings become part of the intersubjective world, available beyond face-to-face situations. Consider examples surrounding the theme of hate and violence. Hate is a subjective state, often expressed through facial expressions and gestures in the here and now. Once haters throw rocks to smash the window of a church, synagogue, or mosque, the communication of meaning no longer depends on such temporary expressions. The broken window and the rocks represent the meaning that motivated the act.

One important type of objectivation is signification, the production of signs that can deliver intended meaning, including hate messages, most powerfully. Instead of breaking a window, anti-Semites may have painted a swastika on the wall of the synagogue. Such signs typically cluster in systems, and language is 
the most significant sign system in the social world. It is more detachable from face-to-face situations than other sign systems. It transcends the here and now most effectively. Language organizes signs. It builds up classification schemes for things such as gender, zones of intimacy, and types of violence. It allows us, for example, to identify and categorize acts of violence as war, terrorism, self-defense, crimes against humanity, or genocide. Within such semantic fields (fields of signs and meanings), biography and history are (selectively) retained, accumulated, and passed on through time.

Via accumulation, groups build a stock of knowledge and transmit it from generation to generation. In the end, the commonsense world of social collectivities is equipped with specific bodies of sedimented knowledge. We know that we share such knowledge with others-and they know that we know. The confidence is mutual, advancing group cohesion and a special sense of trust in other members of our in-groups. Berger and Luckmann also write about language as an aggregate of sedimentations, reaffirmed through symbolic objects, actions, and rituals, providing a sense of reality (on sedimentation as a metaphor, see this book's "Conclusions"). Humans communicate such reality to new generations through processes of socialization. Like the work of Mannheim, a revival of Berger and Luckmann's book has great potential for contemporary sociology, including the sociology of knowledge, as several interventions on the occasion of the fiftieth anniversary of The Social Construction of Reality show (e.g., a special issue of Cultural Socio$\log y$, vol. 10, no. 1, 2016; Knoblauch and Wilke 2016; Presser 2018:9).

This, then, is the antithesis: A world (and history) constructed through objectivation, signification, and sedimentation should be solid, not easily manipulated to align with current circumstances-against Halbwachs's notion of presentism. Who is right, then, when we address genocide knowledge?

The Test Case of "Genocide": From Debate to Legal Doxa. The emergence of legal language about mass violence provides a partial answer to the question just raised. Such language, too, is generated and diffused in personal interaction, and is fluid initially. Eventually, however, legal terms become part of sign systems, doxa, sedimented in the repertoires of law. Remember the conversations in which Lemkin engaged with his professor, and later with international lawyers, conversations that sparked his initial thoughts about the killings of entire social groups (chapter 1). The term genocide grew out of those exchanges, and today we take it for granted. It is part of our categorical system when we seek to interpret situations of mass violence. It is codified in the Convention on the Prevention and Punishment of the Crime of Genocide, passed by the United Nations in 1948, and in the Rome Statute of 1998, the foundation on which is built the International Criminal Court, the first permanent international criminal court. We depend on this concept and on related categories such as crimes against humanity (Lauterpacht 1943) or atrocity crimes (Scheffer 2012) when we think and communicate about mass 
violence. Clearly, international criminal law is an example of a sign system. Symbolic objects, actions, and rituals such as international trials reaffirm the validity of these concepts and the notion that they reflect real phenomena. The category of genocide becomes independent of the interactive contexts from which it emerged.

The Test Case of Genocide: Toward Cultural Trauma. What applies to the concept of genocide also holds true for knowledge about specific instances of mass killings. Again, social interaction and communication contribute to repertoires of knowledge about events such as the Armenian, Cambodian, or Rwandan genocides or the Holocaust. In communication, these historical events, disturbing and confusing initially, take cultural shape. The process of meaning-making begins in the situation of terror, as we learn from survivor narratives (Neurath [1943] 2005; Levi [1986] 2017; Semprún 1981). Eventually, even those who never experienced violence know what occurred, and they may learn to empathize. The dark past becomes part of their world. They may even experience the cultural trauma of victims or of perpetrators, including their descendants and those who learn to identify with them (Alexander et al. 2004).

The late Berkeley sociologist and psychoanalyst Neil Smelser defined cultural trauma as "a memory accepted and publicly given credence by a relevant membership group and evoking an event or situation that is a) laden with negative affect, b) represented as indelible, and c) regarded as threatening a society's existence or violating one or more of its cultural presuppositions" (2004:44). Again, the group is central as a carrier of knowledge, in this case of collective memory or-yet more specifically-cultural trauma. Jeffrey Alexander (2004) adds that cultural trauma is anchored in Émile Durkheim's classical idea of "religious imagination." Such imagination, argues Alexander, forms "inchoate experiences, through association, condensation, and aesthetic creation, into some specific shape" (2004:9). In other words, what once was diffuse and chaotic in the minds of those who experienced horrific events begins to take shape and comes into focus; it becomes organized. Only after such transformation are groups able to communicate effectively about terrifying experiences and potentially share them, as solidified knowledge, with others who were not directly involved.

Like legal concepts, knowledge about specific experiences of mass violence becomes resistant to change, in line with Berger and Luckmann's arguments. This applies to the recognition of genocide, where cultural trauma emerged, for example in the cases of the Shoah or Rwanda. It likewise applies to denial of mass violence, colonialism, and oppression. Consider the memory of Christopher Columbus. Even if today's history textbooks depict Columbus critically, even if social movements portray him as co-responsible for the genocide of indigenous American populations, even if mass media and politicians display sympathy with the victims of the European conquest, the traditional image of Columbus as the "discoverer 
of America" remains dominant in nationally representative opinion polls $(84.7 \%)$ (Schuman, Schwartz, and D’Arcy 2005). Few see him as a villain (3.6\%). Schuman and coauthors attribute such inertia to the institutionalization of the "traditional Columbus" memory through Columbus Day commemoration in schools, paintings, statues, and literature.

Postcommunist Russia partially, but only partially, confirms the notion of mnemonic inertia. In the late twentieth century, a majority of Russians continued to remember the Stalinist purges of 1936-38, especially those who had lived through the period. ${ }^{4}$ They did so despite widespread silencing of this violent chapter of history by the Soviet, and later Russian, state-a case of inertia. Yet the memory dropped off substantially among younger cohorts (Schuman and Corning 2000) proof of the limits of inertia due to an imperfect intergenerational transmission of knowledge in adverse political contexts.

In short, different strands of scholarship are divided, each supported by empirical evidence. Some suggest flexibility and others inertia of knowledge, including knowledge of past mass violence-thesis and antithesis.

\section{Toward Synthesis: Dialogism and Carrier Group Dynamics}

Contemporary scholarship has addressed the tension between inertia and presentism, creatively working toward a synthesis. It holds on to Halbwachs's insights regarding the mutability of knowledge. Yet it simultaneously allows for degrees of inertia, recognizing the weight of sedimentation and endurance of carrier groups. Olick (1999), for example, studied May 8 anniversaries in Germany and asked whether this day in 1945 was commemorated as defeat (of a nation guilty of the crimes of the Nazi regime) or as liberation (of a nation victimized by the Nazi regime). Building on Mikhail Bakhtin's notion of dialogism, in which each utterance is a link in the chain of speech communication, Olick analyzes commemoration of this difficult date for each of the subsequent decades. He finds substantial path dependency, meaning that today's speakers at commemorative events have to take past commemorations (and the reactions they received) into consideration (i.e., inertia). Yet he simultaneously identifies politics of commemoration as speakers take seriously current-day conditions, from the hardship of the immediate postwar era, via exposure to the Frankfurt Auschwitz trial and intergenerational frictions of the 1960 s and 1970s, to rightist violence in post-unification Germany of the 1990 (i.e., presentism). ${ }^{5}$

While Olick displays the simultaneity of the past in the present and the present's manipulation of the past, analyses of Armenian versus Turkish knowledge about the Armenian genocide show that specific conditions allow for flexibility, while others promote inertia. The nature of the knowledge at stake matters, as do the different types of actors who seek to change knowledge. Their interests and institutional positions, their narrative facility, and their epistemic power are crucial factors. 


\section{AMBIGUOUS KNOWLEDGE, KNOWLEDGE \\ ENTREPRENEURS, AND EPISTEMIC POWER \\ IN CONTEXT}

Knowledge about difficult experiences is full of ambiguities, as we have seen: perforated by gaps and silences; marred by contradictions; resulting from struggles between recognition, silencing, and denial. Such features of knowledge may create vulnerabilities, opening up opportunities for revision when strategic actors seek to revise images of history. True for participants in everyday interactions, this holds especially for strategic players, often macro-level actors such as representatives of movements or parties, or heads of organizations or governments. Their institutional positions allow them to reach large audiences, and they are chief promotors of presentist adaptations of knowledge to contemporary interests. Scholarship often refers to them as entrepreneurs, including problem entrepreneurs in the tradition of social problems theory (Schneider 1985), reputational entrepreneurs, or mnemonic or knowledge entrepreneurs. Barry Schwartz (1991; 2003) and Gary Fine (2001) have documented, in multiple case studies, how entrepreneurs shape reputations of past presidents or of entire communities. Their success depends on their motivation, driven by material or ideal interests, and on their institutional placements, their ability to reach large audiences. Clearly, what applies to reputations also affects other types of knowledge, including genocide knowledge. Accordingly, the role of knowledge entrepreneurs will show prominently throughout all of the following chapters.

\section{Narrative Facility and Receptive Audiences}

Narrative facility advances knowledge entrepreneurship. It manifests itself in the skilled use of analogies and narrativization (Rydgren 2007). Consider analogism, the drawing of conclusions from a partial similarity to a similarity in all other respects. This strategy is attractive because it reduces uncertainty-even if it offends against the rules of logic. During the Yugoslav wars of the 1990s, for example, the president of Serbia, Slobodan Milošević, evoked memories of the 1389 Battle of Kosovo between Serbs and troops of the Ottoman Empire to advance his campaign against Bosnian Muslims. He analogized from the aggressive cruelty of the fourteenth-century Ottoman military to the twentieth-century Muslims of the former Yugoslavia, to whom he falsely attributed aggressive tendencies.

Some literature relatedly uses the term analogical bridging - that is, the application of an event that has taken clear cultural shape to a new event that is still confusing. A well-known example is the image of Bosnian Muslims, emaciated, behind the barbed wires of the Omarska concentration camp during the Bosnian civil war. Albeit partially staged, this image, published on title pages of news magazines all over the world, resembled iconic pictures of liberated inmates from Nazi concentration camps and thus evoked memories of the Holocaust. It also 
contributed to the willingness of Western powers to intervene militarily. Effects of skilled analogical bridging can obviously be substantial.

The second way to display narrative facility is skilled narrativization, successful reduction of complexity by bringing events into an order of interconnected sequences. Narrativization often goes along with other forms of simplification, as in Marxist or Christian master narratives that distinguish dichotomously between the righteous and the condemned. Such dichotomization is a common trait of narration in the aftermath of mass violence. Some legal concepts, prominently "genocide," actually require the identification of entire groups as victims-and, by implication, that of other groups as perpetrators. Importantly, narratives about violence not only shape knowledge repertoires, but may also lay the groundwork for future violence or for the slowing of circles of violence, a core theme in narrative criminology (Presser 2018) and in neo-Durkheimian writings about war (Smith 2005). Such narratives may be advanced by rituals, which are the subject of chapter 6 .

One additional condition is required to achieve epistemic change: receptivity of audiences. Receptivity to simplifying narratives is high in times of uncertainty. In such eras, schematized knowledge is in high demand, and leaders who are trusted on the basis of common ethnicity or positions of authority find the greatest resonance. David Garland (2001), seeking to explain excessively punitive attitudes in late modern societies, cites Anthony Giddens's notion of "ontological uncertainty." He argues that elites would not have succeeded in instilling a culture of control on the populace without a general sense of uncertainty, social isolation, and loss of trust in traditional institutions. Like late modernity, post-genocide periods are rife with ontological uncertainty. Old ties have been torn apart, institutions undermined. Limited contact across groups further enhances receptivity to narratives with clear messages and stark images of the other (Rydgren 2007). Context thus codetermines which narratives reach audiences and "what kind of a hearing particular stories secure" (Polletta 2006:167).

\section{Epistemic Power}

Knowledge entrepreneurs succeed best in certifying or modifying knowledge if their narrative facility is supplemented by epistemic power. I approach this difficult term by first clarifying what I mean by power. For the level of social action, especially suited for concrete decision-making processes, Max Weber provides us with his classical definition. He refers to power as "the probability that one actor within a social relationship will be in a position to carry out his will despite resistance, regardless of the basis on which this probability rests" (1978:53). Building on Weber, I have elsewhere coined the term representational power. Specifying the notion for the realm of international criminal justice, I referred to representational power as the chance for international criminal justice institutions to affect collective representations and memories, even against resistance, and thereby to impress on a global public an understanding of mass violence as a form of criminal 
violence (Savelsberg 2020a). More broadly, we may conceive of epistemic power as the chance for actors to affect knowledge repertoires, even (but not necessarily) against resistance, in line with their desired understanding of reality, regardless of the basis on which this probability rests.

The means of epistemic power, the basis on which the probability to affect knowledge rests, are diverse. In the context of genocide knowledge, actors may practice power through the initiation and structuration of rituals (a mechanism explored in chapter 6); through the threat of economic or diplomatic sanctions or military force in international relations, or the risk that ethnic blocks will withdraw voter support in electoral politics (mechanisms explored in chapter 7); or by the use of legal resources (as analyzed in chapter 8 ). All of these strategies may enhance the ability of some actors (and reduce that of others) to certify, diffuse, or regulate knowledge.

In the context of state action, special kinds of power to which social actors attribute legitimacy play an important role. Weber calls them authority or domination. Submission to the will of others here involves a voluntary element, a belief in the justification of command. Such justification may be based on a "belief in the appropriate enactment of impersonal statutes and regulations" (Kalberg 2005:xxii). A case in point is obedience to legislatively imposed language regulations that criminalize either genocide denial or the articulation of genocide history. Court judgments are another example of legal-rational authority, and struggles over court decisions that pertain to speech rights versus restrictions on hate speech show the importance that current societies attribute to this mechanism (see chapter 8). Perceived justification of authority or domination may rest, alternatively, on charisma, whereby "obedience results from a belief in and devotion to the extraordinary sanctity and heroism of an individual person" (Kalberg 2005:xxii). It may finally be rooted in tradition, when "obedience results from an established belief in the sanctity of immemorial traditions and the legitimacy of those exercising rulership under them (for example, clan patriarchs)" (Kalberg 2005:xxix-xxx). Indeed, obedience based on old age or religion is relevant in our context, because many Armenians and many Turks are closely wedded to religious communities - the Armenian Apostolic Church and the Hanafi school of Sunni Islam, respectively.

The notion of legitimacy also fares prominently in Pierre Bourdieu's concept of symbolic power, a tacit mode of cultural domination unfolding within everyday social habits and belief systems (Bourdieu 1984). For Bourdieu, symbolic power is "the form that the various species of capital [economic, social, cultural] assume when they are perceived and recognized as legitimate" (Bourdieu 1989:17). Symbolic capital thus enables its holders to use their economic, social, or cultural capital in order to impose ideas and knowledge on others. They are unlikely to face resistance. The term hegemony, to which I return in chapter 9, is closely related. 


\section{STRUCTURAL CONTEXTS OF GENOCIDE \\ KNOWLEDGE: INSTITUTIONS, NATIONS, AND HISTORICAL TIME}

Narrativization and the practice of power happen not in a vacuum, but in the context of social fields-for example, legal and political fields (and the institutions embedded in them). Each social field follows its own rules of the game, and institutions are endowed with specific institutional logics.

\section{Institutions and Their Rules of the Game (Institutional Logics)}

Consider criminal trials and the stories, silencing, denial, and acknowledgment they generate. Their narratives tend to focus on individuals, relatively short time frames, and the need to arrive at binary guilty/not guilty decisions. They are also contingent on specific evidentiary criteria that differ from those accepted, for example, in the world of scholarship. Under such conditions, participants act in predictable ways. Defendants, when confronted with overwhelming evidence, tend to respond with implicatory denial. In genocide trials, they tell a story in which they were ignorant of the atrocities, or at least lacked agency, and are thus not guilty. By engaging in implicatory denial, however, they implicitly acknowledge the violence and its interpretation as crime, possibly as genocide. ${ }^{6}$ Yet theirs is not the only story told in trials. In the adversarial setting of a criminal court, the other side will challenge the defendant's story and the denial it entails. Victim groups and their representatives contest incomplete confessions.

A series of effective trials advance at least partial acknowledgment. Their force may help explain differences between post-World War II Germany and postWorld War I Turkey. International trials in the case of Germany are famous, and domestic trials there extended over decades. In Turkey, by contrast, there were no international trials and the domestic trials took place only in 1919-20. The latter trials reached guilty verdicts against some perpetrators, but opponents successfully challenged the legitimacy of the proceedings (Göçek 2015).

\section{Nation-States as Contexts}

In addition to social fields and institutional settings, societal contexts also affect the chances of truth claims to settle in collective knowledge repertoires. Consider country contexts in which institutions and social fields are embedded. Recently, Mark Wolfgram (2019) demonstrated the weight of national contexts on knowledge about the past in his comparative study of legacies of war and genocide in Germany, Japan, Spain, Yugoslavia, and Turkey. His comparison highlights the explanatory weight of generational distance, generated by nation-specific cultural assumptions about strong families, patriarchy, collectivism, and tradition versus individualism. These forces impede critical distance toward the past, including in generations that follow the perpetrators, and Turkey provides a strong 
illustration (Wolfgram 2019:185ff). In other contexts, where acknowledgment and confessions prevail, they may lead to a contentious coexistence at the societal level that is wholesome for democratic development, as Payne (2008) observes in her study on confessions in transitional justice contexts and as Göçek (2015) hopes for Turkey. Yet at the level of families and communities, a price may have to be paid in the currency of discord and conflict.

Like perpetrator knowledge, knowledge repertoires of victim groups are also contingent on national context, especially a victim group's proportional representation. Wholesome effects of verbal silencing described by Carol Kidron (2009) for the families of Holocaust victims in Israel seem to be weaker or absent in the diaspora, as stories told by Philippe Sands (2016) illustrate (see chapter 1).

Importantly, though, nation-states are embedded in global contexts, in world society. Effects of nation-level action are always contingent on forces emanating from world society (a theme I engage with in chapter 9).

\section{Historical Context and Cohorts}

Historical context, especially temporal and generational distance from the genocide, may also affect knowledge repertoires. In Germany in the first decades after the Holocaust, silencing prevailed, as did implicatory denial in specific contexts such as trials. Later, silencing by the perpetrator generation gave way to acknowledgment. At times, members of younger generations struggled for comprehensive, including implicatory, acknowledgment. In other societal contexts, in which silence and denial have been successfully institutionalized, such generational patterns are missing. Turkey is a prime example. Turkish intellectuals such as Fatma Müge Göçek are not alone with their insistence on acknowledgment, but they are exceptions.

Where societies have reached broad consensus about past violence as an instance of mass atrocity and genocide, the pressure on individuals and families to acknowledge those facts intensifies. Yet such acknowledgment sets in motion opposite tendencies at the level of small, intimate groups, especially families, that often seek to redefine actions by elders in ways that exculpate those involved in the history of perpetration (Welzer et al. 2002). Grandchildren who have strong ties with their grandparents experience intense dissonance when affection clashes with information about mass atrocities that is taught in school, described in literature, or uttered in public discourses - atrocities in which their grandparents' generation had been involved. Even if grandpa was a member of the SS in Nazi Germany or of the Special Organization in Turkey, grandchildren will likely find ways to exculpate him. They may reason that he did not join voluntarily, or that he was not in the places where atrocities were committed. Implicatory denial on behalf of a grandparent then becomes a common form of stigma management-but, again, it is associated with factual and interpretive acknowledgment. 


\section{CONCLUSIONS: HARVESTING THEORETICAL TOOLS}

In sum, repertoires of knowledge, including knowledge about mass violence, past and present, are associated with group membership. Some types of knowledge stick to specific groups with particular ease, especially if they grow out of those groups' experience. We refer to these as carrier groups. Knowledge repertoires build up through thousands and millions of day-to-day interactions. They are captured in enduring signs and symbols, which are sediments of social communication. Consequently, inertia is one attribute of such bodies of knowledge.

Yet knowledge is not immutable. Knowledge repertoires, especially those entailing ambiguous knowledge, are receptive to mutations, especially when knowledge entrepreneurs are involved. Knowledge entrepreneurs are actors who are motivated to shape knowledge, who occupy privileged institutional positions with access to channels of communication, and who master narrative facility. An additional condition for their success is public receptivity, often the result of uncertainty and social isolation. In such contexts, knowledge entrepreneurs may hold substantial epistemic power. Yet they have to contend with context: social fields, institutions, nation-states, historical time, and generational patterns within which they seek to establish, or revise, repertoires of genocide knowledge.

In short, sociological literature offers us a set of conceptual and theoretical tools with which to trace and possibly explain conflicting knowledge repertoires held by Armenians and Turks about the events of 1915 and subsequent years, their inertia, and their transformations - a task to which I turn next. 